\title{
Firing transformations of an argentinean calcareous commercial clay
}

\section{(Transformações de queima de uma argila de calcário comercial argentino)}

\author{
M.F. Serra ${ }^{1,2}$, M .S. Conconi ${ }^{1,2,3}$, G. Suarez $z^{1,3,4}$, E. F. Agietti ${ }^{1,3,4}$, N. M. Rendtorff $f^{1,2,3}$ \\ ${ }^{I}$ Centro de Tecnología de Recursos Minerales y Cerámica (CETMIC): (CIC-CONICET-CCT La Plata), Camino \\ Centenario y 506, C.C.49 (B1897ZCA) M.B. Gonnet, Buenos Aires, Argentina \\ ${ }^{2}$ CIC-PBA, Buenos Aires, Argentina \\ ${ }^{3}$ Facultad de Ciencias Exactas, Universidad Nacional de La Plata - UNLP, Argentina \\ ${ }^{4}$ CONICET, Buenos Aires, Argentina \\ rendtorff@cetmic.unlp.edu.ar
}

\begin{abstract}
Mineralogical transformations caused by firing are usually studied by XRD methods only semi-quantitatively. In this work the original mineral disappearance and the neo-mineralization were evaluated quantitatively. Furthermore an indirect non crystalline phase quantification was performed under $1100{ }^{\circ} \mathrm{C}$ was also carried out using the quartz content as internal standard. This study specifically discusses the behavior of an Argentinean white calcareous earthenware commercial when subjected to traditional ceramic firing, besides the technological importance of this particular material, it acts as a model for other clay based ceramic materials. Materials were subjected to thermal treatments between $700{ }^{\circ} \mathrm{C}$ and $1100{ }^{\circ} \mathrm{C}$. A preliminary sintering characterization was carried out by contraction and porosity evolution. Simultaneous thermogravimetric and differential thermal analysis (TG-DTA) was carried out to elucidate the actual temperature at which the chemical changes occur. Finally, a quantitative analysis based on the Rietveld refinement of the X-ray diffraction patterns was performed to characterize the crystalline phases present in both the clay and in the materials obtained after different thermal treatments. The actual chemical reactions are proposed. The phases identified after firing at traditional working temperature $\left(1040^{\circ} \mathrm{C}\right)$ are quartz, plagioclase, and the Spinel type alumino-silicate, accompanied by the non-diffracting un-reacted metakaolin and some amount of amorphous glassy phase. At intermediate temperatures $\left(900{ }^{\circ} \mathrm{C}\right)$ the presence of gehlenite was also detected. The carbonates (calcite and dolomite) presence and decomposition were also evaluated and demonstrated to determine the sintering characteristics of this material.
\end{abstract}

Keywords: silicate ceramic processing, structure, X-ray diffraction.

\section{Resumo}

Transformações mineralógicas causadas por queima são estudadas pelo método semiquantitativo de difração de raios $X$. $O$ desaparecimento do mineral original e o neomineral foram avaliados quantitativamente. Além disso, a quantificação de fase não cristalina foi alcançada acima de $1000^{\circ} \mathrm{C}$, sendo usado quartzo como padrão. Este estudo descreve um calcário branco argentino comercial, o qual é submetido a uma queima cerâmica tradicional, com base na sua importância tecnológica, ele atua como modelo para outras argilas com base cerâmica. Os materiais foram submetidos a tratamento térmico entre $700{ }^{\circ} \mathrm{C}$ e $1000{ }^{\circ} \mathrm{C}$. Uma caracterização preliminar da sinterização foi avaliar a evolução da retração e da porosidade. Análise simultânea termogravimétrica e térmica diferencial foi realizada para determinar as temperaturas em que ocorrem mudanças químicas. Finalmente, foi feita uma analise quantitativa com base no refinamento Rietveld dos padrões de difração de raios $X$, para caracterizar as fases cristalinas na argila e nos materiais obtidos após os tratamentos térmicos. As reações químicas que ocorrem são propostas. As fases identificadas após a queima na temperatura tradicional de trabalho $\left(1040{ }^{\circ} \mathrm{C}\right)$ são quartzo, plagioclásio, e o espinélio tipo aluminio-silicato, juntamente com metacaulim não detetado e algum teor de fase vítrea. Foi também determinada gehlenita em temperaturas intermediarias $\left(900^{\circ} \mathrm{C}\right)$. A presença e a decomposição de carbonatos (calcita e dolomita) foram também avaliadas e demonstrada sua atuação nas características da sinterização.

Palavras-chave: processamento de cerâmica de silicato, estrutura, difração de raios $X$.

\section{INTRODUCTION}

The sintering temperature is one of the most important processing variables in the manufacture of ceramic pieces. In fact, in some cases, it defines the final product costs. Accurate measurement, prediction and predetermination of material properties are important for its posterior use, and undoubtedly the properties depends on both the phase (crystalline and non crystalline) composition and microstructure of the final ceramic material.

Ceramic clays are one of the most complicated ceramic systems because of the non simple relationship between the behavior of minerals during the ceramic processing and the transformations during heating. A major challenge is to predict the phase transformations in silicate ceramics, since non simple relationships occur between the structural 
characteristics of the fired products and the physical properties.

During ceramic process, once the crystalline structures of minerals exceed their stability limits, they are partially decomposed while simultaneously others are being formed. The destruction of the pre-existing structure does not occur instantaneously. Moreover these transformations determine the final properties of the ceramic products [14]. Firing transformations of calcareous clays used in the manufacturing of ceramic tiles [5-8] were also studied.

Upon firing, the minerals in the clay bodies undergo chemical and structural modifications deeply transforming the original materials. The high temperature, low-pressure mineral transformations are mainly influenced by the chemical and mineralogical compositions of the original clay, its grain-size distribution, the maximum heating temperature, heating rate, duration of firing and kiln redox atmosphere $[9,10]$. Firing transformation inside traditional ceramic kilns was extensively reported in the literature, but usually this kind of evaluation is carried out qualitatively and not quantitatively. The presence of gehlenite and anorthite phases in fired clays which were originally composed of illite, Kaolinite, quartz and calcite was verified [1]. The relationship between the mineralogical composition of the raw materials and the phase changes during sintering was also examined for other clay based ceramic materials $[1-8,11]$. Several investigators have studied the mineralogical transformations in fired $\mathrm{Ca}$ rich clays in comparison with Ca-poor clays [12-18]. The new phases typically reported are gehlenite, wollastonite and anorthite, formed from initial materials with about $50 \% \mathrm{SiO}_{2}, 15 \% \mathrm{Al}_{2} \mathrm{O}_{3}$ and $10 \% \mathrm{CaO}$. The formation of gehlenite and calcic plagioclase in calcareous clays has been established. The presence of gehlenite and anorthite phases when firing clays which were originally composed of illite, kaolinite, quartz and calcite [1]. As shown there is a significant volume of literature on the disappearance and the neo-mineralization by firing in ceramic kilns. This study specifically discusses the behavior of an Argentinean white calcareous earthenware commercial when subjected to traditional ceramic firing, besides the technological importance of this particular material, it acts as a material model for other clay based ceramic materials.

Mineralogical transformations caused by firing are usually studied by XRD methods only semi-quantitatively [12-18]. In this work a quantitative analysis of the thermal evolution of crystalline and none (low) crystalline phases is carried out by means of the Rietveld method [19]. The method developed by H. Rietveld (1969) to refine crystalline structures using neutron diffraction data, extended its use to structural analysis, cell parameters measurement, phase transformations, quantitative analysis of mineral mixtures [20] and to determination of amorphous content by X-ray diffraction, between other uses [21]. Overcoming the complexity of these natural samples, this kind of analysis can also be applied to clay based materials with promising results [22]. This method fits point-to-point the difference between experimental intensities of the whole X-ray pattern and the calculated intensities, based on a certain model of crystalline structure, optic effects of diffraction, instrumental factors and other characteristics of the sample. The parameters included in the model are refined until the best least square fit of the thousands profile points is obtained.

\section{EXPERIMENTAL PROCEDURES}

\section{Materials processing}

A ceramic paste from commercial white earthenware ("Pasta blanca lisa" earthenware commercial formula Chilavert SA, Argentina) was studied. Prismatic specimens of $8 \times 8 \times 60 \mathrm{~mm}^{3}$ were elaborated by plastic forming and dried to constant weight in an oven at $100{ }^{\circ} \mathrm{C}$. They were then fired at different temperatures between 700 and $1100{ }^{\circ} \mathrm{C}$ with a heating (and cooling) rate of $10^{\circ} \mathrm{C} / \mathrm{min}$, and a $15 \mathrm{~min}$ of soaking time. The selected temperature range was chosen because the earthenware is usually fired at $980{ }^{\circ} \mathrm{C}$ (Orton standard cone 06) in the first firing usually known as biscuit fire, and the second glazing firing is usually carried out in the $1020-1040{ }^{\circ} \mathrm{C}$ range (cone 05).

Table I - Chemical composition of dried calcareous clay (clay) and of a sampled fired at $1050{ }^{\circ} \mathrm{C}(1050)$.

[Tabela I - Composição química de argila calcário seca e de uma amostra calcinada a $1050^{\circ} \mathrm{C}$.]

\begin{tabular}{|c|c|c|}
\hline & $\begin{array}{l}\text { As received } \\
\text { dried clay } \\
\text { (wt. } \%)\end{array}$ & $\begin{array}{c}\text { Fired ceramic } \\
\text { material }\left(1040{ }^{\circ} \mathrm{C}\right) \\
(\text { wt. } \%)\end{array}$ \\
\hline $\mathrm{SiO}_{2}$ & 70.85 & 76.84 \\
\hline $\mathrm{Al}_{2} \mathrm{O}_{3}$ & 12.81 & 13.89 \\
\hline $\mathrm{Fe}_{2} \mathrm{O}_{3}$ & 0.61 & 0.66 \\
\hline $\mathrm{TiO}_{2}$ & 0.53 & 0.57 \\
\hline $\mathrm{CaO}$ & 3.62 & 3.93 \\
\hline $\mathrm{MgO}$ & 1.65 & 1.79 \\
\hline $\mathrm{Na}_{2} \mathrm{O}$ & 0.15 & 0.16 \\
\hline $\mathrm{K}_{2} \mathrm{O}$ & 2.00 & 2.17 \\
\hline LOI & 7.80 & \\
\hline Total & 100 & 100 \\
\hline \multicolumn{3}{|c|}{ Properties } \\
\hline \multicolumn{2}{|c|}{ Mass loss after drying (\%) } & 19.8 \\
\hline \multicolumn{2}{|c|}{ Green density $\left(\mathrm{g} / \mathrm{cm}^{3}\right)$} & 1.94 \\
\hline \multicolumn{2}{|c|}{ Green porosity (\%) } & 28.3 \\
\hline \multicolumn{2}{|c|}{ Mass loss after drying (\%) } & 19.8 \\
\hline
\end{tabular}

Chemical analysis of a dried clay sample (clay) and of a sampled fired at $1050{ }^{\circ} \mathrm{C}(1050)$ is shown in Table I. In the same table, some properties of the unfired materials are shown, this values are typical for these kind of materials used in the local ceramic industry. 
Texture and thermal evolution of the calcareous commercial clay

Green density was evaluated by mercury immersion technique. Density and open porosity of sintered samples were determined by the water absorption method. Permanent linear contraction $(\mathrm{C})$ in the mentioned temperature range was performed to preliminarily analyze the sintering behavior commercial clay.

The effect of heat treatment was also evaluated by thermogravimetric analysis and differential thermal analysis (DTA-TG) simultaneously carried out on a Netzsch 409C equipment. A complementary dilatometric analysis was performed for both, the green samples and the sintered $\left(1040{ }^{\circ} \mathrm{C}\right)$ material. This is the actual sintering temperature industrially used for this kind of earthenware. Prismatic specimens $\left(8.0 \times 8.0 \times 50.0 \mathrm{~mm}^{3}\right)$ were analyzed in air atmosphere with a Netzsch 402 dilatometer. Both the heating and cooling rates were $5{ }^{\circ} \mathrm{C} / \mathrm{min}$ in all cases.

Identification and quantification of crystalline phases in the calcareous clay and in the fired materials were carried out by X-ray diffraction (XRD) (Philips 3020 with $\mathrm{Cu}-\mathrm{k} \alpha$ radiation, Ni filter, at $40 \mathrm{kV}-20 \mathrm{~mA}$ ). The XRD patterns were analyzed with the program FullProf (version 4.90, July 2010) which is a multipurpose profile-fitting program, including Rietveld refinement to perform phase quantification.

Quartz grains do not reveal any appreciable morphological and chemical transformation until $1050{ }^{\circ} \mathrm{C}$. At this point, quartz grains show as a rule, microtextural evolution of albite and micas are irrespective of the clay composition. On the contrary, the transformation of calcite and the wider reaction layer around quartz are only produced within the Ca-rich clay [14]. For this reason in this study the quartz was employed as invariant internal standard.

When adding an internal standard to a sample, if any non crystalline phase is present, the internal standard content would be overestimated by the Rietveld analysis. The percentage of amorphous (glassy) phase in the sample can be estimated using the following equation [21]:

$$
\mathrm{NC} \%=100-\sum_{\mathrm{i} \text {-phases }}\left(\mathrm{C}_{\mathrm{i}} \times \frac{\mathrm{W}_{\mathrm{Q}}}{\mathrm{C}_{\mathrm{Q}}}\right)
$$

where $\mathrm{NC} \%$ is the non crystalline content, $\mathrm{W}_{\mathrm{Q}}$ is the internal standard (quartz) weight $\%, \mathrm{C}_{\mathrm{Q}}$ is the internal standard content evaluated by the Rietveld method and $\mathrm{C}_{\mathrm{i}}$ is the i-phase content. For this reason to obtain the actual phase content of each present phase they should be corrected by the amorphous phase evaluated.

\section{RESULTS AND DISCUSSION}

\section{Starting crystalline phases}

XRD was employed to determine and quantify the crystalline phases of the commercial clay. Particularly the Rietveld method was employed to quantify each phase. Fig. 1 shows the diffraction pattern of the as received $\left(110^{\circ} \mathrm{C}\right.$ dried) original sample for $2 \theta$ between $3^{\circ}$ and $70^{\circ}$. The main diffraction peaks are marked. Table II shows the actual content (weight basis) of each of the detected crystalline phases.

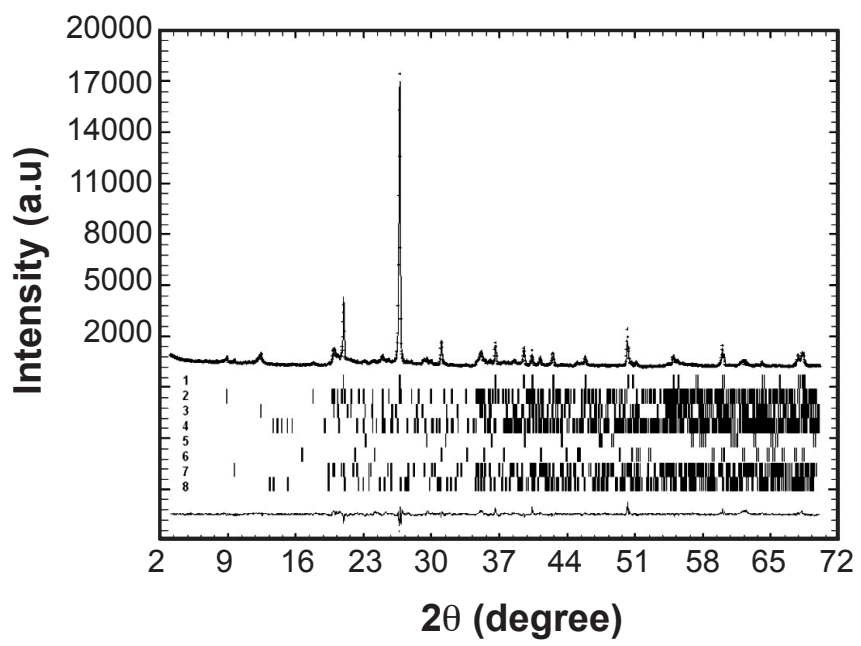

Figure 1: XRD-Rietveld pattern of the as received material. 1 Quartz, 2 Illite, 3 Kaolinite, 4 Plagioclase-Oligoclase (Ca-Na), 5 Calcite; 6 Dolomite, 7 Pyrophyllite, 8 Feldspar (K).

[Figura 1: Padrão DRX-Rietveld do material como recebido. 1 Quartzo, 2 Illita, 3 Caulinita, 4 Plagioclásio-Oligoclásio (CaNa), 5 Calcita, 6 Dolomita, 7 Pirofilita, 8 Feldspato 8 (K).]

As expected for this the commercial calcareous material, quartz $(\mathrm{Q})$ and clays $(\mathrm{C})$ are the principal crystalline phases; the sum of $\mathrm{Q}$ and $\mathrm{C}$ is over $90 \%$. The flux fraction of the original sample is composed principally of carbonates and traces of feldspars. Particularly dolomite $\left(\mathrm{MgCa}\left(\mathrm{CO}_{3}\right)_{2}\right)$ and

Table II - Crystalline composition of the as received material. [Tabela II - Composição cristalina do material como recebido.]

\begin{tabular}{cccc}
$\begin{array}{c}\text { Crystalline } \\
\text { phase }\end{array}$ & $\begin{array}{c}\text { Content } \\
\text { wt.\% }\end{array}$ & Type & $\begin{array}{c}\text { Content } \\
\text { wt.\% }\end{array}$ \\
\hline Quartz & $\begin{array}{c}47.4 \\
\text { Illite }\end{array}$ & Quartz & 47.4 \\
Kaolinite & 23.0 & Clays & 43.8 \\
Pyrophyllite & 8.0 & & \\
Calcite & 1.2 & Carbonates & 7.5 \\
Dolomite & 6.3 & & \\
Na-Ca Feldspar & 0.8 & Feldspars & 1.5 \\
(Plagioclase) & & & \\
K Feldspar & 0.7 & & \\
\hline
\end{tabular}

calcite $\left(\mathrm{CaCO}_{3}\right)$ are the principal fluxing contributions, this fact gives the name to this particular commercial clay.

The clay fraction of the materials is composed mainly by 
kaolinite (over the $50 \%$ of the clay). The complementary clays are illite and pyrophyllite. The low amount of $\mathrm{Al}_{2} \mathrm{O}_{3}$ (Table II) together with the detected presence of these complement clays and the other impurities suggest a moderately low refractoriness of this clay. Finally, the amount of iron $(\mathrm{Fe})$ in the chemical composition together with the crystalline phase analysis suggests that the firing colour will not be completely white, In fact the firing samples presented a very light beige firing colour, however this commercial material is known as a white clay.

\section{Textural properties}

Porosity (P), water absorption (WA), density (D) and contraction (C) evolution with firing temperature were measured in order to evaluate the sinterability of the calcareous commercial clay. The results are shown in Fig. 2. Generally, these clays are biscuit fired at around $980{ }^{\circ} \mathrm{C}$ and fired at $1040{ }^{\circ} \mathrm{C}$ for the second glaze firing. This preliminary analysis corroborated that this is in fact a limiting temperature. The four properties remained stable up to $1040-1050{ }^{\circ} \mathrm{C}$ and at $1100{ }^{\circ} \mathrm{C}$ changed abruptly.

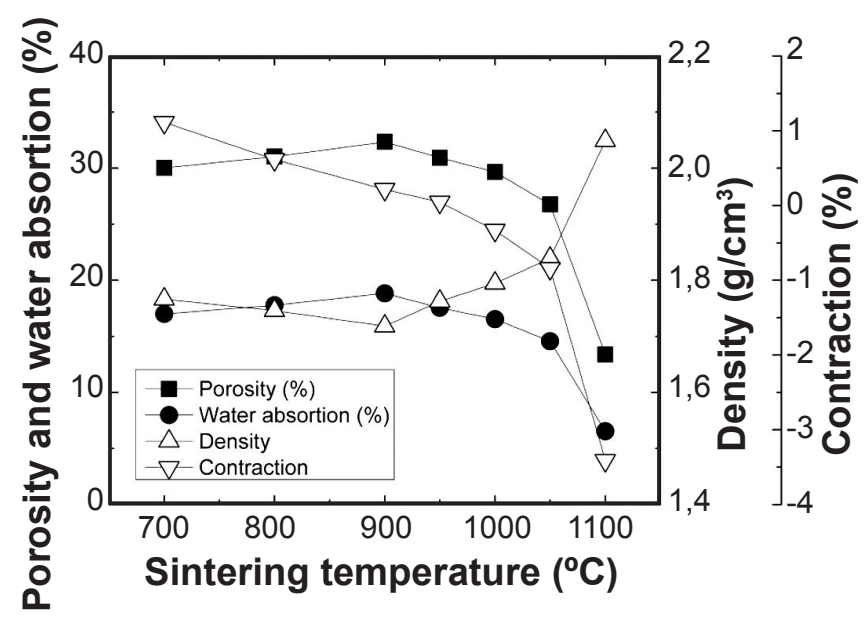

Figure 2: Porosity (P), water absorption (WA), sintered density (D) and linear contraction (C) as a function of the sintering temperature of the white calcareous earthenware.

[Figura 2: Porosidade (P), adsorção de água (WA), densidade do sinterizado $(D)$ e retração linear $(C)$ em função da temperatura de sinterização da cerâmica calcária branca.]

The under fired $\left(700{ }^{\circ} \mathrm{C}-900{ }^{\circ} \mathrm{C}\right)$ materials presented an enlargement after the thermal treatment that decreased with the temperature. No size change was detected for the material fired at $1000{ }^{\circ} \mathrm{C}$ and a not negligible $3 \%$ contraction was observed for the over fired material $\left(1100{ }^{\circ} \mathrm{C}\right)$. The enlargement is related to the clay decomposition that was evaluated in the following sections. Between $900{ }^{\circ} \mathrm{C}$ and $1000{ }^{\circ} \mathrm{C}$, the sintering process consists in the aggregation and compaction of particles. As this process is not complete, the ceramic bodies are quite porous. The reduction of water absorption is linked to the increase in the bending strength of the clay matrix and the thermal expansion of the ceramic piece increases. As a first glance P, WA and D remained stable up to $1000{ }^{\circ} \mathrm{C}$; a slight variation after 900 ${ }^{\circ} \mathrm{C}$ could be detected, showing that before this temperature some mineralization started and were detected by DTA and XRD analysis. Results are shown in the following sections. Finally, it can be point out that the evaluated values of P, WA and D correspond to earthenware [23]. Another remarkable result is the observed stability of the properties in this wide temperature range which make them unsuitable for quality control parameters. Instead, a mechanical characterization is suggested.

\section{Dilatometry}

Fig. 3 shows the dilatometry of this material in green and sintered at $1040{ }^{\circ} \mathrm{C}$ (temperature usually used for the manufacture of earthenware). The expansion, assumed to be the derivative of the first one, is shown in Fig. 3 as well.

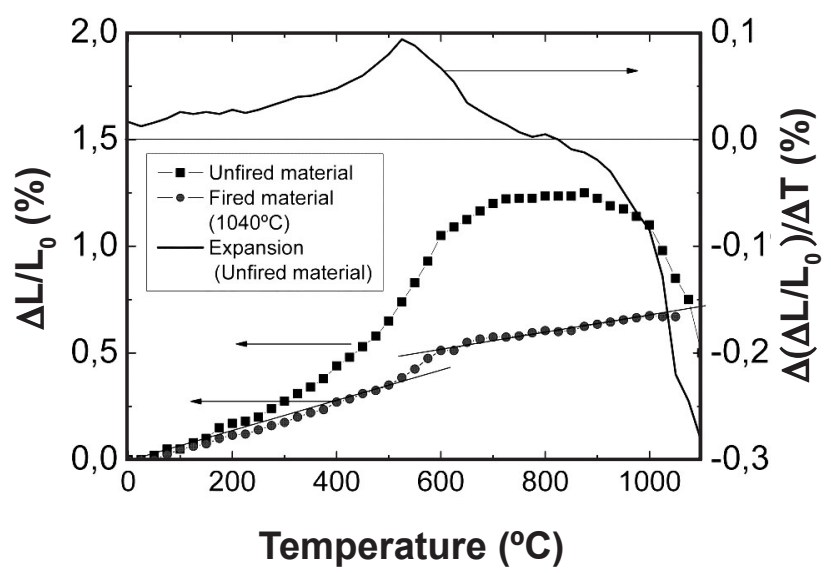

Figure 3: Dilatometry of the green and sintered $\left(1040{ }^{\circ} \mathrm{C}\right)$ calcareous clay.

[Figure 3: Dilatometria do compacto verde e sinterizado $\left(1040{ }^{\circ} \mathrm{C}\right)$ da argila calcária.]

For de unfired clay, the expansion grows up to $550{ }^{\circ} \mathrm{C}$, from that temperature expansion decreases to $800{ }^{\circ} \mathrm{C}$ then the graph presents a plateau until $900{ }^{\circ} \mathrm{C}$ temperature at which begins the contraction, This contraction becomes abrupt after $1050^{\circ} \mathrm{C}$. This behaviour show that the maximum temperature is critical for the sintering of these materials. The sharp contraction at high temperatures illustrates the short maturity range. Hence this kind of clays cannot be used for dense stoneware. Dilatometry of the sintered material (Fig. 3) shows a discontinuity around $500-600{ }^{\circ} \mathrm{C}$. Two linear ranges can be easily observed below and over this temperature. This discontinuity corresponds to the $\alpha-\beta$ transformation of quartz [23]. The linear expansion coefficients can be calculated for both linear ranges (0$500{ }^{\circ} \mathrm{C}$ and $600-1040{ }^{\circ} \mathrm{C}$ ). The expansion coefficients were calculated as the slope of the linear fit by the method of least squares. Both fitting presented good linear correlation $\left(\mathrm{R}^{2} \geq 0.97\right.$ in both cases). The result showed a significant difference in each temperature range $\left(8.410^{-6}{ }^{\circ} \mathrm{C}^{-1}\right.$ and 
$3.210^{-6}{ }^{\circ} \mathrm{C}^{-1}$, respectively). Finally, the actual expansion coefficient from $25{ }^{\circ} \mathrm{C}$ to $1000{ }^{\circ} \mathrm{C}$ was $6.810^{-6}{ }^{\circ} \mathrm{C}^{-1}$. This is the last value that should be taken into account for the coupling of this body with the later glazes. Anyway, since it is a porous material (30\%), this discontinuity hardly brings big problems with breakages. At high firing rates this could really become a problem.

\section{Simultaneous thermogravimetric and differential} thermal analysis (TG-DTA)

Fig. 4 shows the DTA/TG curve recorded from the powder of the calcareous commercial clay. A broad endothermic band centred at $538{ }^{\circ} \mathrm{C}$, due to clay dehydroxylation reaction that is overlapped with $\alpha-\beta$ quartz transformation of less energy involved, is the most important peak of the DTA analysis. The following equations illustrate this processes, while the first one is irreversible, the second one is not, depending on the final temperature achieved.

$$
\begin{aligned}
& \mathrm{AL}_{2} \mathrm{O}_{3} \cdot 2 \mathrm{SiO}_{2} \cdot 2 \mathrm{H}_{2} \mathrm{O} \stackrel{\approx 5400^{\circ} \mathrm{C}}{\longrightarrow} \mathrm{AL}_{2} \mathrm{O}_{3} \cdot 2 \mathrm{SiO}_{2} \cdot 2 \mathrm{H}_{2} \mathrm{O}(\mathrm{B}) \\
& \alpha-\mathrm{SiO}_{2} \stackrel{573^{\circ} \mathrm{C}}{\longrightarrow} \beta-\mathrm{SiO}_{2}
\end{aligned}
$$

The mass loss associated to this endothermic peak is $3.1 \%$. To consider that this mass loss is only due to the kaolinite decomposition is a good assumption; hence kaolinte content can be estimated in $22.3 \%$. This peak is accompanied by four other peaks: A small endothermic peak at $100{ }^{\circ} \mathrm{C}$ which is correlated with the surface adsorbed water, also a small exothermic peak is observed at $340{ }^{\circ} \mathrm{C}$, this peak evidenced the presence of illitic clays in the original formula [14]. Later, the carbonate decomposition is evident at $787^{\circ} \mathrm{C}$, a small endothermic peak can be observed. Finally the pre-mullite spinel type phase formation at $980{ }^{\circ} \mathrm{C}$ could be detected, the mullite is formed from this phase that is difficult to detect by XRD.

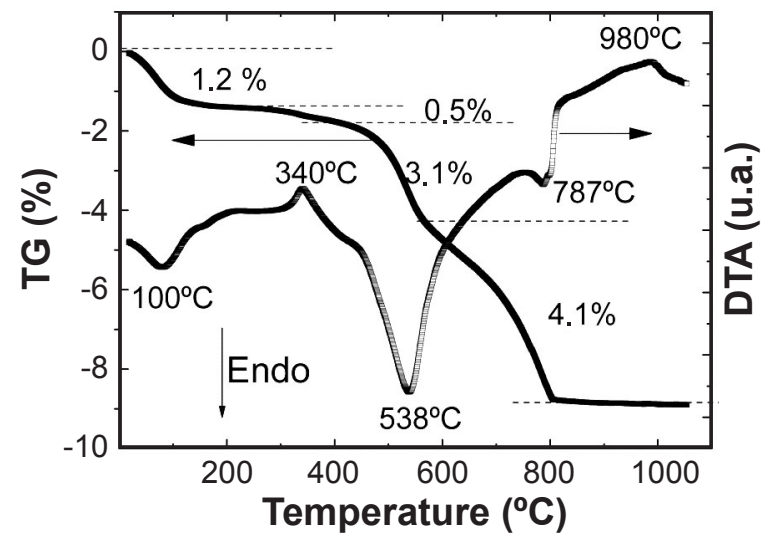

Figure 4: Thermal evolution of the white calcareous earthenware. Simultanous DTA-TG analysis.

[Figura 4: Evolução térmica da cerâmica calcária branca. Análise simultânea ATD-TG.]

The exothermic peak at $980{ }^{\circ} \mathrm{C}$ has previously been assigned [24] to the transformation of the Al coordination from the pentahedral or tetrahedral form of the metakaolinite to the octahedral form. In this exothermic reaction, amorphous silica, the spinel-like phase, and nuclei of mullite are produced. This spinel like phase can difficultly be detected by XRD [24], only the three broad peaks can be detected at $37^{\circ}$, $46^{\circ}$, and $67^{\circ}$ associated with a cubic phase. From this analysis it can be conclude that the studied formula corresponds to a kaolinitic-illitic clay with important alkaline earth metals (Ca and $\mathrm{Mg}$ ) carbonates presence. Particularly for samples fired at $800{ }^{\circ} \mathrm{C}$, the carbonate decomposition (calcite and dolomite) is incomplete, Dolomite decompose firstly into a kind of calcite, which afterwards (twenty or forty degrees higher) decompose like the calcite already present in the starting formula $[25,26]$. However a more accurate analysis was carried out by means of XRD diffraction and Rietveld refinement. This is shown in section 3.4. It is also important to point out that the mass loss of the fired (over $800{ }^{\circ} \mathrm{C}$ ) samples is of around $8 \mathrm{wt} . \%$. This consists in the addition

Table III - Crystalline phases of the green and fired earthenware evaluated by the Rietveld method.

\begin{tabular}{|c|c|c|c|c|c|c|}
\hline \multicolumn{2}{|c|}{ Firing temperarure $\left({ }^{\circ} \mathrm{C}\right)$} & 0 & 800 & 900 & 1000 & 1100 \\
\hline \multicolumn{2}{|r|}{ Quartz } & $47.4(1.5)$ & $77.8(2.4)$ & $80.7(2.3)$ & $79.0(2.1)$ & $66.5(2.2)$ \\
\hline \multirow{3}{*}{ Clays } & Illite & $12.8(0.9)$ & $11.4(1.2)$ & $9.0(1.3)$ & - & - \\
\hline & Kaolinite & $23.0(1.8)$ & - & - & - & - \\
\hline & Pyrophyllite & $8.0(1.8)$ & $4.0(1.0)$ & - & - & - \\
\hline \multirow{2}{*}{ Carbonates } & Calcite & $1.2(0.5)$ & $3.7(0.6)$ & - & - & - \\
\hline & Dolomite & $6.3(1.1)$ & - & - & - & - \\
\hline \multirow{4}{*}{$\begin{array}{l}\text { Neo Mineralized } \\
\text { Phases: } \\
\text { Feldspars } \\
\text { Aluminosilicates } \\
\text { and others. }\end{array}$} & Na-Ca Feldspar & $0.8(0.2)$ & $2.4(0.3)$ & $5.7(0.8)$ & $11.7(1.2)$ & $18.3(1.8)$ \\
\hline & K Feldspar & $0.7(0.3)$ & $0.7(0.2)$ & $1.0(0.2)$ & $1.0(0.2)$ & $1.0(0.3)$ \\
\hline & Gehlenite & & & $4.6(0.9)$ & & \\
\hline & Mullite and Pre-Mullite & - & - & - & $9.2(1.1)$ & $14.2(1.5)$ \\
\hline
\end{tabular}

[Tabela III - Fases cristalinas da cerâmica a verde e sinterizada avaliadas pelo método de Rietveld.] 
of water and carbon dioxide liberation from the mineral decomposition during the firing processes. The actual crystalline phase evolution was evaluated and the results are shown in the following section. From this analysis is that the amount of carbonate is really lower than the calcareous rich clays evaluated recently [17] with lost more than $20 \%$ of mass after similar thermal treatments.

\section{Evolution of crystalline phases}

Fig. 5 shows the diffraction patterns the samples submitted to different thermal treatments and compared with the as received material. Table III shows the results of the XRD-Rietveld, identification and quantification. As mentioned three clay minerals were detected, the principal one is Kaolinite and is accompanied by illite and phyrofilite, while the first one decompose below $800{ }^{\circ} \mathrm{C}$ the other two decomposes after $900{ }^{\circ} \mathrm{C}$ treatments, the amount of Kaolinite evaluated by the Rietveld was equal to the one estimated from the TG analysis in section 3.3. As mentioned the carbonate decompositions occurs in two steps [26]. The following equations illustrated this processes:

$$
\begin{aligned}
& \mathrm{CaMg}\left(\mathrm{CO}_{3}\right)_{2 \text { (cryst) }} \stackrel{\mathrm{T}<750^{\circ} \mathrm{C}}{\longleftrightarrow} \mathrm{CaCO}_{3(\text { (ryst) }}+ \\
& \mathrm{MgO}_{\text {(non-cryst) }}+\mathrm{CO}_{2 \text { (gas) }}
\end{aligned}
$$

$$
\mathrm{CaCO}_{3 \text { (cryst) }} \stackrel{750^{\circ} \mathrm{C}<\mathrm{T}<900^{\circ} \mathrm{C}}{\longrightarrow} \mathrm{CaO}_{\text {(non-cryst) }}+\mathrm{CO}_{2 \text { (gas) }}
$$

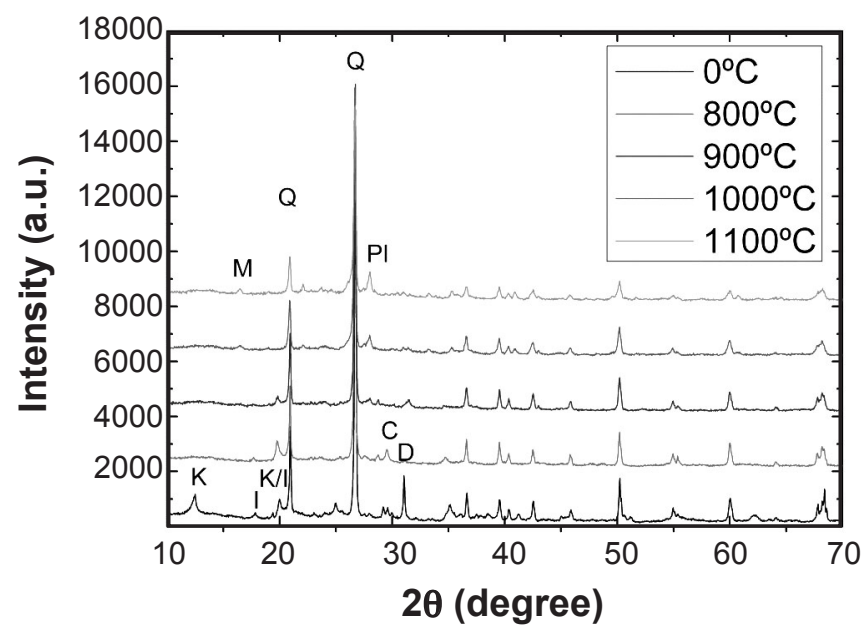

Figure 5: X-ray diffraction patterns of the green earthenware and fired at different temperatures. Q: Quartz, K: Kaolinite, I: Illite, D: Dolomite, C: Calcite, M: Mulllite, Pl: Plagioclase.

[Figura 5: Difratogramas de raios $X$ da cerâmica a verde e sinterizada a diferentes temperaturas. Q: Quartzo, K: Caulinita, I: Ilita, D: Dolomita, C: Calcita, M: Mulllita, Pl: Plagioclásio.]

This is the reason why the amount of calcite after $800{ }^{\circ} \mathrm{C}$ treatments is higher than the starting quantity. After $900{ }^{\circ} \mathrm{C}$ treatments no carbonates are detected. No important amount of feldspars were detected in the original material, however, a gradual increment in the plagioclase content was detected consequence of the thermal treatments. After $1100{ }^{\circ} \mathrm{C}$ the amount of feldspar reaches almost $20 \%$ of the crystalline phases of the earthenware. Taking into account that below $1100{ }^{\circ} \mathrm{C}$ quartz shows no important modification [23] and that no quartz is formed from these starting phases as a consequence of the thermal treatment; hence, it can be used as internal standard for the estimation of the non-crystalline and glassy phase [21]. The metakaolin does not present important XRD manifestations [23]. For practical purpose, in this work, we assume that metakaolin belongs to the first group.

Table IV shows the results of the non crystalline phase estimation carried out by the described methodology. Although in Table III the amount of quartz evaluated was $47.4 \mathrm{wt} . \%$ for the non crystalline estimation $\mathrm{W}_{\mathrm{Q}}$ was assumed to be $51.4 \%$, because of the $8 \%$ mass loss consequence of the metakaolin formation and the carbonate decomposition observed and evaluated by TG analysis in section 3.3. the amount ok kaolinite evaluated by the two methods (ATD-

Table IV - Non crystalline phase of the green and fired earthenware, using quartz $(\mathrm{Q})$ as internal standard.

[Tabela IV - Fase não cristalina da cerâmica a verde e sinterizada, usando quartzo $(Q)$ como padrão interno.]

Non-crystalline phase $\%$

Firing temperature $\left({ }^{\circ} \mathrm{C}\right) \quad \mathrm{NC} \%=100-\sum_{\text {i-phases }}\left(\mathrm{C}_{\mathrm{i}} \times \frac{\mathrm{W}_{\mathrm{Q}}}{\mathrm{C}_{\mathrm{Q}}}\right)$

\begin{tabular}{cc}
\hline 0 & 0 \\
800 & 33,9 \\
900 & 35,7 \\
1000 & 34,3 \\
1100 & 22,7 \\
\hline
\end{tabular}

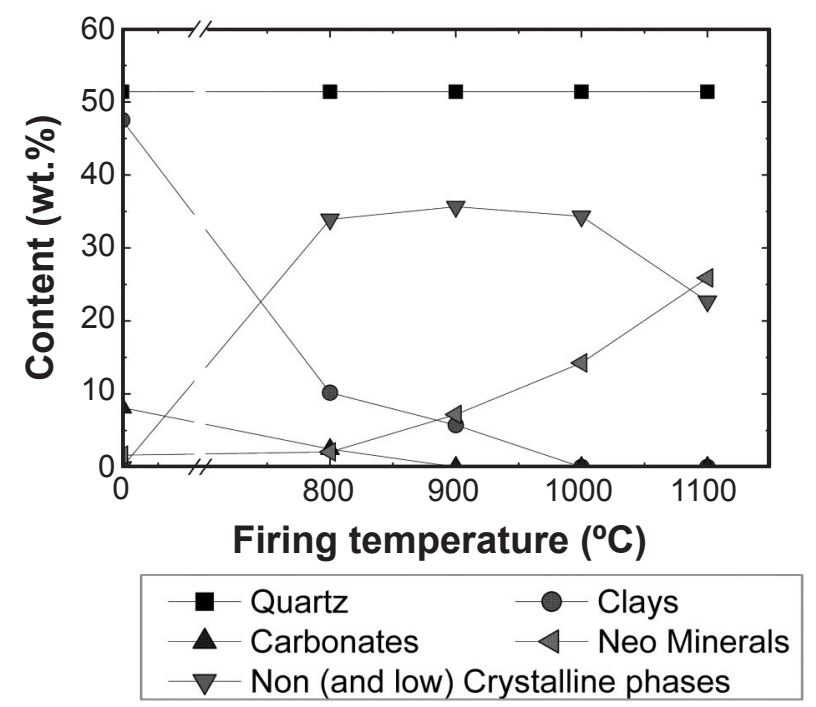

Figure 6: Thermal phase evolution of the white calcareous earthenware.

[Figura 6: Evolução térmica da cerâmica calcária branca.] 
TG) and the XDR-Rietveld was equivalent.

In Fig. 6 the amount of non-crystalline and glassy phase as a function of the temperature of the thermal treatment is plotted; in the same graph the different mineral types were grouped.

The calcareous earthenware is composed mostly of clay minerals (52\%) and quartz (40\%) accompanied by carbonates (calcite and dolomite) and some (less than $2 \%)$ feldspars (plagioclase and microcline). Generally the firing transformations include the decomposition of the clay minerals and the carbonates. The crystallinity of these products is low. Later, different crystalline phase neomineralize, as seen in the DTA-TG analysis (section 3.3) at $800{ }^{\circ} \mathrm{C}$ the complete decomposition of the kaolinite is observed, however the remaining clay minerals decompose between this temperature and $900{ }^{\circ} \mathrm{C}$. In samples treated at $900{ }^{\circ} \mathrm{C}$ gehlenite $\left(\mathrm{Ca}_{2} \mathrm{Al}\left(\mathrm{AlSiO}_{7}\right)\right.$ is detected $(5 \%)$, but at higher temperatures this phase is not present, while the plagioclase ( $\mathrm{Na}$ and $\mathrm{Ca}$ feldspar) content increases with temperature. The plagioclases detected are mainly "anorthe type" with high calcium content. This fact can be explained by the combination of the $\mathrm{CaO}$ released by carbonate decomposition with alumina and silica provided by clay decomposition to produce first gehlenite and then plagioclase [14]. At higher temperatures (over $1150{ }^{\circ} \mathrm{C}$ ) this will decompose (melt) again. The amount of non crystalline phases at these intermediate temperatures is around 35\%(800 ${ }^{\circ} \mathrm{C}-900{ }^{\circ} \mathrm{C}$ ). From $1000{ }^{\circ} \mathrm{C}$ on, some spinel type aluminosilicate crystallize (section3.3) from the metakaolinite, this phase is usually known as pre-mullite and also has low crystallinity and is not easily detected by XRD [23]. At higher temperature mullite $\left(3 \mathrm{Al}_{2} \mathrm{O}_{3} \cdot 2 \mathrm{SiO}_{2}\right)$ crystallizes [23]. But these temperatures exceed the range usually used for these materials. As this type of calcareous earthenware is usually fired below $1100{ }^{\circ} \mathrm{C}$, in fact the most common firing temperatures are $1040{ }^{\circ} \mathrm{C}$ and $1020^{\circ} \mathrm{C}$, that correspond to the 05- and 06 Orthon standard cones [27], the expected phases to be present in the final product are quartz, plagioclase, and the spinel type alumino-silicate, accompanied by the non diffracting un-reacted metakaolinite and some amount of amorphous glassy phase.

\section{CONCLUSIONS}

Firing transformation inside traditional ceramic kilns was extensively reported in the literature, but usually this kind of evaluation is carried out qualitatively and not quantitatively. This work intends to fulfill this by applying the Rietveld refinement method. A preliminary sintering characterization was carried out by contraction and porosity evolution with the maximum temperature achieved during the processing. And confirmed the traditional firing treatments applied to this kind of materials $\left(1040{ }^{\circ} \mathrm{C}\right)$. Also some neomineralization was suggested by this macroscopic analysis. The thermal behavior characterization was also carried out to elucidate the actual temperature at which the chemical changes occur. From this analysis it can be conclude that the studied formula corresponds to kaoliniticillitic clay with important alkaline $(\mathrm{Ca}$ and $\mathrm{Mg}$ ) carbonate presence. However, a more accurate crystalochemical evolution of the formula could be carried out by the XRD analysis. Finally a quantitative analysis based on the Rietveld refinement method of the X-ray diffraction patterns was carried out to characterize the presence of crystalline phases in the materials after different thermal treatments. Also with the non crystalline phases estimation. This was carried out by the internal standard method, assuming that quartz was unchanged during the firing below $1100{ }^{\circ} \mathrm{C}$. The Rietveld refining method showed to be a suitable tool for this analysis. The technological value of these results is clear; the actual chemical reactions are proposed. At intermediate temperatures $\left(900^{\circ} \mathrm{C}\right)$ the presence of gehlenite was also detected. Furthermore, the carbonates (calcite and dolomite) presence and decomposition was also evaluated and established. Finally the expected phases at traditional working temperature $\left(1040{ }^{\circ} \mathrm{C}\right)$ are quartz, plagioclase, and the spinel type alumino-silicate, accompanied by the non diffracting un-reacted metakaolin and some amount of amorphous glassy phase. The presence of the pre-mullite phase, with aluminum with an octahedral coordination, was detected by ATD, and not detected by XRD, only indirectly by the proposed internal standard method.

\section{REFERENCES}

[1] F. González-García, V. Romero-Acosta, G. GarcíaRamos, M. González-Rodríguez, Firing transformations of mixtures of clays containing illite, Kaolinite and calcium carbonate used by ornamental tile industries, Appl. Clay Sci. 5, 4 (1990) 361-375.

[2] M. M. Jordán, A. Boix, C. De la Fuente, E. Ballbé, I. Queralt, T. Sanfeliu, Mineralogía y propiedades cerámicas de arcillas cretácicas wealdienses de Castellón, Bol. Soc. Esp. Mineralogía 17 (1994) 135-143.

[3] M. M. Jordán, A. Boix, T. Sanfeliu, C. De La Fuente, Firing transformations of cretaceous clays used in the manufacturing of ceramic tiles, Appl. Clay Sci. 14, 4 (1999) 225-234.

[4] M. M. Jordán, A. Boix, T. Sanfeliu, C. De La Fuente, The mineralogy of Cretaceous clays in Castellon and their application in the ceramic industry, Int. Ceram. J. 10 (1995) 25-29.

[5] M. M. Jordán, J. D. Martín-Martín, T. Sanfeliu, D. Gómez-Gras, C. de la Fuente, Mineralogy and firing transformations of Permo-Triassic clays used in the manufacturing of ceramic tile bodies, Appl. Clay Sci. 44, 1-2 (2009) 173-177.

[6] M. M. Jordan, M. A. Montero, S. Meseguer, T. Sanfeliu, Influence of firing temperature and mineralogical composition on bending strength and porosity of ceramic tile bodies, Appl. Clay Sci. 42, 1-2 (2008) 266-271.

[7] M. M. Jordán, T. Sanfeliu, C. de La Fuente, Firing transformations of Tertiary clays used in the manufacturing of ceramic tile bodies, Appl. Clay Sci. 20, 1-2 (2001) 87-95. 
[8] M. M. Jordán, T. Sanfeliu, C. de la Fuente, E. Ballbé, Ceramic interest Weald clays from Castellon, Third EuroCeramics 2 (1993) 947-952.

[9] M. Maggetti, "Phase analysis and its significance for technology and origin", Archaeological Ceram. (1982) pp. 121-133.

[10] A. Moropoulou, A. Bakolas, K. Bisbikou, Thermal analysis as a method of characterizing ancient ceramic technologies, Thermochim. Acta 269-270 C (1995) 743-753. [11] V. Das Kshama, B. V. Mohan, M. Lalithambika, C. G. R. Nair, Sintering studies on plastic clays, Ceram. Int. 18, 6 (1992) 359-364.

[12] T. Peters, R. Iberg, Mineralogical changes during firing of calcium-rich brick clays, Am. Ceram. Soc. Bull. 57 (1978) 503-509.

[13] P. Duminuco, B. Messiga, M. P. Riccardi, Firing process of natural clays. Some microtextures and related phase compositions, Thermochim. Acta 321, 1-2 (1998) 185-190.

[14] M. P. Riccardi, B. Messiga, P. Duminuco, An approach to the dynamics of clay firing, Appl. Clay Sci. 15, 3-4 (1999) 393-409.

[15] G. Cultrone, C. Rodriguez-Navarro, E. Sebastian, O. Cazalla, M. J. De La Torre, Carbonate and silicate phase reactions during ceramic firing, Eur. J. Mineralogy 13, 3 (2001) 621-634.

[16] K. Traoré, T. S. Kabré, P. Blanchart, Gehlenite and anorthite crystallisation from Kaolinite and calcite mix, Ceram. Int. 29, 4 (2003) 377-383.

[17] M. J. Trindade, M. I. Dias, J. Coroado, F. Rocha, Mineralogical transformations of calcareous rich clays with firing: A comparative study between calcite and dolomite rich clays from Algarve, Portugal, Appl. Clay Sci. 42, 3-4 (2009) 345-355.

[18] F. Pardo, S. Meseguer, M. M. Jordán, T. Sanfeliu, I.
González, Firing transformations of Chilean clays for the manufacture of ceramic tile bodies, Appl. Clay Sci. 51, 1-2 (2011) 147-150.

[19] H. M. Rietveld, A profile refinement method for nuclear and magnetic structures, J. Appl. Crystallography 2 (1969) 65-71.

[20] D. L. Bish, J. E. Post, Quantitative mineralogical analysis using the Rietveld full-pattern fitting method, Am. Mineralogist 78 (1993) 932-940.

[21] M. S. Conconi, N. M. Rendtorff, E. F. Aglietti, Evaluation of Non Crystalline Phase in AZS Refractories by XRD Methods, New J. Glass Ceramics 1, 2 (2011) 21-25.

[22] R. D. Bonetto, P. E. Zalba, M. S. Conconi, M. Manassero, The Rietveld method applied to quantitative phase analysis of minerals containing disordered structures, Rev. Geol. Chile 30, 1 (2003) 103-115.

[23] W. M. Carty, U. Senapati, Porcelain - Raw materials, processing, phase evolution, and mechanical behaviour, J. Am. Ceram. Soc. 81, 1 (1998) 3-20.

[24] J. Sanz, A. Madani, J. M. Serratosa, J. S. Moya, S. Aza, Aluminum-27 and Silicon-29 Magic-Angle Spinning Nuclear Magnetic Resonance Study of the KaoliniteMullite Transformation, J. Am. Ceram. Soc. 71, 10 (1988) C418-C421.

[25] G. Cultrone, C. Rodriguez-Navarro, E. Sebastian, O. Cazalla, M. J. De La Torre, Carbonate and silicate phase reactions during ceramic firing, Eur. J. Mineralogy 13, 3 (2001) 621-634.

[26] S. Gunasekaran, G. Anbalagan, Thermal decomposition of natural dolomite, Bull. Mater. Sci. 30, 4 (2007) 339-344. [27] H. Evele, R. Hayes, Using pyrometric cones to monitor firing of porcelain enamel ware: Plant and laboratory trials, Ceram. Eng. Sci. Proc. 18, 5 (1997) 81-91.

(Rec. 31/05/2012, Ac.02/11/2012) 